\title{
Determination of Iron, Copper and Zinc in the Wine by FAAS Valon Durguti ${ }^{a^{*}}$, Suzana Aliu ${ }^{\text {a }}$, Fisnik Laha ${ }^{\text {a }}$, Fidan Feka ${ }^{\text {a }}$ \\ ${ }^{a}$ Department of Food Science and Technology, University of Business and Technology (UBT), Lagjja Kalabria p.n.10 000 Prishtina, Republic of Kosovo
}

\begin{abstract}
Objectives: The purpose of this paper has been to determine quantitatively the presence of some heavy metals $(\mathrm{Fe}, \mathrm{Cu}$, and $\mathrm{Zn}$ ) which are of particular importance for the wine quality and human health. A total of 41 samples have been analyzed during different stages of winemaking. Methods: The determination of heavy metals is done by an analytical technique known as Flame Atomic Absorption Spectroscopy (FAAS). The limit set by the EU directive EC 606/2009 and International Office of Vine and Wine (OIV) has been taken as reference values. Results and Discussion: None of the analyzed samples has exceeded the limits set by the EU and OIV, excluding the type of white wine known as Rhine Riesling. In this sample the $\mathrm{Cu}$ concentration exceeds several times the permissible values. Findings: It has been observed that heavy metals immediately after the alcoholic fermentation process probably continue to remain even for a while in the upper part until wine sediment forms at the bottom of the tank. A higher concentration of heavy metals was observed in the samples taken from the bottom of the wine tank. Conclusion: The analyzed wines samples do not pose a risk in the future to human health.
\end{abstract}

\section{Keywords:}

Flame Atomic Absorption Spectroscopy;

Heavy Metals;

Iron, Copper, Zinc ;

Wine.

\section{Article History:}

$\begin{array}{llll}\text { Received: } & 20 & \text { July } & 2020 \\ \text { Accepted: } & 28 & \text { September } & 2020 \\ \text { Published: } & 01 & \text { October } & 2020\end{array}$

\section{1- Introduction}

Without any doubt, wine is widely consumed beverage in the world with very obvious commercial value and social importance. The mineral content of wines may be influenced by many factors such as mineral composition of soil, viticultural practices, environmental conditions, processing, clarification procedures or storage conditions [1]. Metals in wine can originate from both natural and anthropogenic sources, and its concentration can be a significant parameter affecting consumption and conservation of wine. Metallic ions have an important role in oxide-reductive reactions, resulting in the wine browning, turbidity, cloudiness, astringency, and wine quality depends greatly on its metal composition [2].

Several elements (especially $\mathrm{Cd}, \mathrm{Cu}, \mathrm{Fe}, \mathrm{Mn}, \mathrm{Sn}$ and $\mathrm{Zn}$ ) when present in excessively high concentration in wines, adversely affect the organoleptic quality and the stability of the wine [3]. Several metals and metalloids, such as Cd, $\mathrm{Pb}, \mathrm{Sn}, \mathrm{Hg}$, and $\mathrm{As}$, are known to be potentially toxic. At the same time, the analysis for certain elements in wines and fruit wines is of special interest due to their toxicity in case of excessive intake and also the effect they seem to have on the organoleptic properties of these alcoholic beverages. A typical example is copper which is an essential as well as a potentially toxic element for humans when in excess [4]. In contrast, the excessive presence of the elements like $\mathrm{Al}, \mathrm{Cu}, \mathrm{Fe}$, and $\mathrm{Zn}$ has a definite negative effect on the organoleptic properties of the different kinds of wine [5].

Class A metals are essential for life in relatively high amounts (for example iron), class B includes metals that have no known biological function but are not particularly toxic at low concentrations (for example strontium), class $\mathrm{C}$ includes metals that are essential in very low concentrations (copper, molybdenum, nickel, manganese, and zinc), but which at higher than certain threshold concentrations may become toxic, and finally class $\mathrm{D}$, which includes metals

\footnotetext{
* CONTACT: Valon.durguti@ubt-uni.net

DOI: http://dx.doi.org/10.28991/esj-2020-01240
}

(C) 2020 by the authors. Licensee ESJ, Italy. This is an open access article under the terms and conditions of the Creative Commons Attribution (CC-BY) license (https://creativecommons.org/licenses/by/4.0/). 
that are toxic even at low levels and their biological function is unclear (cadmium, mercury, and lead). The concentration of heavy metals can vary during different technological stages of winemaking. The mineral content of wines may be influenced by many factors such as mineral composition of soil, viticultural practices, environmental conditions, processing, clarification procedure or storage conditions. Heavy metals, decreased during fermentation, resulting in $0-50 \%$ of original amount. Increased concentrations in wine resulted from contamination during postfermentation processing [6]. Increased concentration of heavy metals in the wine may result from long maceration times, and long contact times with metal-containing equipment. Yeasts also consume metals such as copper, iron, and zinc.

A large number of symptoms/ailments, comprising anemia, depressed growth, dermatitis, dwarfism, electrolyteimbalance, gastro-intestinal and neurological disorders, lethargy and nausea, have been associated with $\mathrm{Cu}$ and $\mathrm{Zn}$ deficiency in humans, as well as with toxicity due to excessive intake [7].

\section{2- Materials and Methods}

The method we have used has been described by the Thermo-Scientific Company (Part of Thermo Fisher Scientific) [1]. Sampling was done at the Agrokosova Holding Company, the winery which operates in southern part of Kosovo, and three other wine samples for comparison have been taken from Macedonia. International standards of wine sampling have been applied, and sampling has been done during different technological stages of winemaking. A total of 41 samples were analyzed. Sample analyzes were performed in the laboratories of the University of Business and Technology - UBT (Prishtina - Kosovo). The analytical technique which has been used to determine heavy metals concentration in the wine has been Flame Atomic Absorption Spectroscopy (FAAS).

The Organisation International de la Vigne et du Vin (OIV) recommends a maximum $\mathrm{Cu}$ content of $1.0 \mathrm{mg} / \mathrm{L}$ for wines. The International Office of Vine and Wine (OIV) has also set minimum limits for As $(0.2 \mathrm{mg} / \mathrm{L}), \mathrm{Cd}(0.01$ $\mathrm{mg} / \mathrm{L}), \mathrm{Pb}(0.2 \mathrm{mg} / \mathrm{L})$ and $\mathrm{Zn}(5 \mathrm{mg} / \mathrm{lL}$. The OIV also recommends that wines should contain Fe below $10 \mathrm{mg} / \mathrm{l}$.

\section{2-1- Standards and Sample Preparation}

The type of flame atomic absorber that we have used was Perkin Elmer AA 300. In the beginning, the stock standard solution for iron, copper and zinc with known concentration of $1000 \mathrm{mg} / \mathrm{L}$ was prepared. All certified reference materials (standards) are obtained from the company C.P.A. Chem. Then, iron, copper, and zinc stock standard solutions containing $1000 \mathrm{mg} / \mathrm{L}$ were diluted with a pre-mixed solution of de-ionized water and analytical grade concentrated nitric acid (HNO3), to provide working standard solution of known concentrations in $2 \%$ (w/v) HNO3. The blank solution used for calibration was a $2 \%(\mathrm{w} / \mathrm{v})$ HNO3. For zinc, working standards solutions were 0.5 $\mathrm{mg} / \mathrm{L}, 1 \mathrm{mg} / \mathrm{L}$ and $2 \mathrm{mg} / \mathrm{L}$, while for iron and copper the working standard solutions were $1 \mathrm{mg} / \mathrm{L}, 5 \mathrm{mg} / \mathrm{L}$, and $10 \mathrm{mg} / \mathrm{L}$. From each wine sample $10 \mathrm{ml}$ was accurately measured and transferred into a $40 \mathrm{ml}$ volumetric flask. After that, 0.8 $\mathrm{ml}$ of analytical grade HNO3 was added and then made up to the final volume of $40 \mathrm{ml}$ with Ultra-Pure DI Water. Iron, copper and zinc were determined by AAS in the air-acetylene flame using standard calibration curves.

Table 1. The instrument settings of Flame Atomic Absorber - Perkin Elmer AA 300.

\begin{tabular}{cccc}
\hline Fe & Zn & Cu \\
\hline Wavelength (nm) & 248.3 & 213.9 & 324.8 \\
Fuel flow rate & $0.9 \mathrm{~L} / \mathrm{min}$ & $1.1 \mathrm{~L} / \mathrm{min}$ & $1.2 \mathrm{~L} / \mathrm{min}$ \\
Correlation coefficient & 0.9925 & 0.9468 & 0.904 \\
Replicates & 3 & 3 & 3 \\
Read time & $4 \mathrm{~s}$ & $4 \mathrm{~s}$ & $4 \mathrm{~s}$ \\
Unit & mg/L & mg/L & mg/L \\
Flame type & Air-Acetylene & Air-Acetylene & Air-Acetylene \\
\hline
\end{tabular}




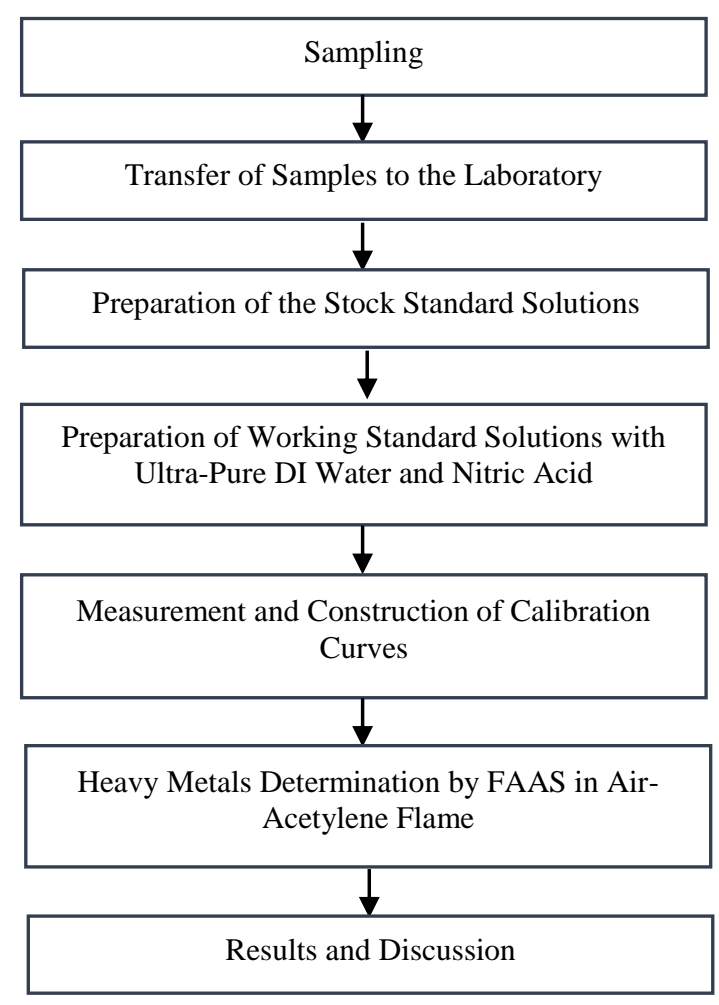

Figure 1. Flowchart of the research methodology.

\section{3- Results and Discussion}

The limit set by the European Union for iron in the wine is less than $30 \mathrm{mg} / \mathrm{L}$, or according to the International Organisation of Vine and Wine (OIV) less than $10 \mathrm{mg} / \mathrm{L}$. Most of the heavy metals in the grapes precipitate during fermentation into the sediments, which is the reason for their significantly lower content in the wine [8]. The application of fining agents, such as bentonite, copper sulfate ( $\mathrm{Al}, \mathrm{Ca}, \mathrm{Cd}, \mathrm{Cr}, \mathrm{Cu}, \mathrm{Fe}, \mathrm{Zn}$ ) and other environmental pollution $(\mathrm{Cd}, \mathrm{Co}, \mathrm{Cr}, \mathrm{Hg}, \mathrm{Ni}, \mathrm{Pb}, \mathrm{V})$ may contribute also to wine contamination [9]. From the obtained results (Table 2) we can see that in the samples taken immediately after the alcoholic fermentation process there may still be relatively high concentrations of heavy metals in the upper part of the wine tank. This is due to impurity precipitation process which has been probably underway. As an example we can take the results of the wine type known as Pinot Noir (Table 2). We can see that in the upper part of the wine tank, the concentration of iron is higher compared to the bottom, a process which probably changes over time, up to in wine purification and sediment formation. The clarification and filtration are two common technological processes during winemaking. The potential negative impact of wine clarification and filtration has also been observed.

The application of these two technological processes it seems likely to induce increased concentration of iron in the wine. All this probably as a result of the wine passage through the technological equipment used for this purpose, or even passing through the special oenological pipes which are widely used during winemaking. Probably the wine pipes contain the impurity or even the composition of the equipment may affect the increase of iron concentration in the wine. As an example, it is worth analyzing the results of the wine type Pinot Blanc (Table 2). We can see that after applying the filtration process, the increased concentration of iron in the wine has been observed. We can support and compare these findings with the different articles of our colleagues who point out that one of the real possibilities of increasing the concentration of heavy metals in the wine may also be the use of oenological practices such as machinery, piping, use of fining agents, additives, etc. [2]. Regarding the Fe in wines, the main problem that appears is instability of wines when Fe concentration is greater than $10 \mathrm{mg} / \mathrm{l}$. However, from the obtained results we can conclude that none of the analyzed samples poses a risk for significant wine instability in the future, especially after wine bottling and aging. These wines do not pose a risk for human health too. 
Table 2. The Iron ( $\mathrm{Fe})$ concentration in the wine.

\begin{tabular}{|c|c|c|c|c|c|}
\hline Type of Wine & $\begin{array}{c}\text { Year of } \\
\text { Production }\end{array}$ & Country & $\begin{array}{l}\text { The Sampling Part } \\
\text { in the Wine Tank }\end{array}$ & $\begin{array}{c}\text { The Technological Stage } \\
\text { During Winemaking }\end{array}$ & $\begin{array}{l}\mathrm{Fe}(\mathrm{mg} / \mathrm{L}) \text { after } \\
\text { three replication }\end{array}$ \\
\hline Pinot Blanc & 2017 & Kosovo & The bottom & After fermentation & 0.464 \\
\hline Pinot Blanc & 2017 & Kosovo & Upper part & After filtration & 1.470 \\
\hline Rhine Riesling & 2017 & Kosovo & The bottom & After fermentation & 2.483 \\
\hline Rhine Riesling & 2017 & Kosovo & Upper part & After clarification & 1.148 \\
\hline Franconia & 2017 & Kosovo & The bottom & After fermentation & 0.958 \\
\hline Franconia & 2017 & Kosovo & Upper part & After fermentation & 1.011 \\
\hline Sauvignon Blanc & 2017 & Kosovo & Upper part & After filtration & 1.721 \\
\hline Merlot & 2017 & Macedonia & Upper part & After fermentation & 1.346 \\
\hline Vranac & 2017 & Macedonia & Upper part & After fermentation & 1.576 \\
\hline Cabernet Sauvignon & 2017 & Macedonia & Upper part & After fermentation & 1.506 \\
\hline
\end{tabular}

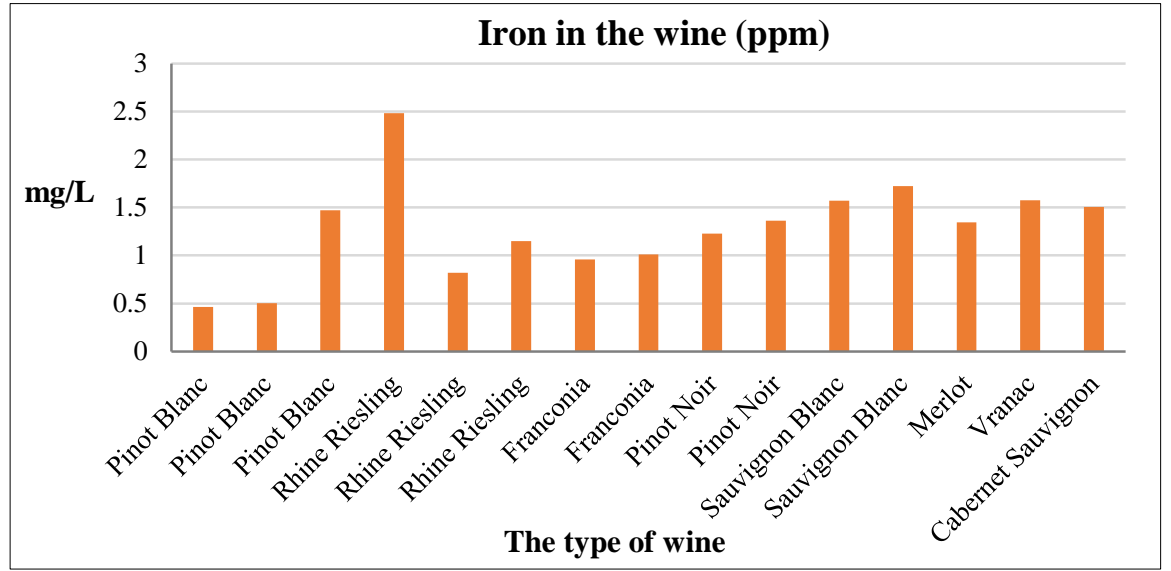

Figure 2. The iron concentration $(\mathrm{mg} / \mathrm{L})$ in the wine.

Table 3. The concentrations of cupper $(\mathrm{mg} / \mathrm{L})$ in the wine.

\begin{tabular}{cccccc}
\hline Type of Wine & $\begin{array}{c}\text { Year of } \\
\text { Production }\end{array}$ & Country & $\begin{array}{c}\text { The Sampling Part } \\
\text { in the Wine Tank }\end{array}$ & $\begin{array}{c}\text { The Technological Stage } \\
\text { During Winemaking }\end{array}$ & $\begin{array}{c}\text { Cu (mg/L) after } \\
\text { three replication }\end{array}$ \\
\hline Pinot Blanc & 2017 & Kosovo & The bottom & After fermentation & 0.037 \\
Pinot Blanc & 2017 & Kosovo & Upper part & After fermentation & 0.037 \\
Pinot Blanc & 2017 & Kosovo & Upper part & After filtration & 0.030 \\
Rhine Riesling & 2017 & Kosovo & The bottom & After fermentation & 0.066 \\
Rhine Riesling & 2017 & Kosovo & Upper part & After fermentation & 0.056 \\
Rhine Riesling & 2017 & Kosovo & Upper part & After clarification & 0.088 \\
Franconia & 2017 & Kosovo & The bottom & After fermentation & After fermentation \\
Franconia & 2017 & Kosovo & Upper part & After fermentation & 0.121 \\
Pinot Noir & 2017 & Kosovo & The bottom & After fermentation & 0.124 \\
Pinot Noir & 2017 & Kosovo & Upper part & After fermentation \\
Merlot & 2017 & Macedonia & Upper part & After fermentation & 0.158 \\
Vranac & 2017 & Macedonia & Upper part & After fermentation & 0.127 \\
Cabernet Sauvignon & 2017 & Macedonia & Upper part & & 0.149 \\
\hline
\end{tabular}




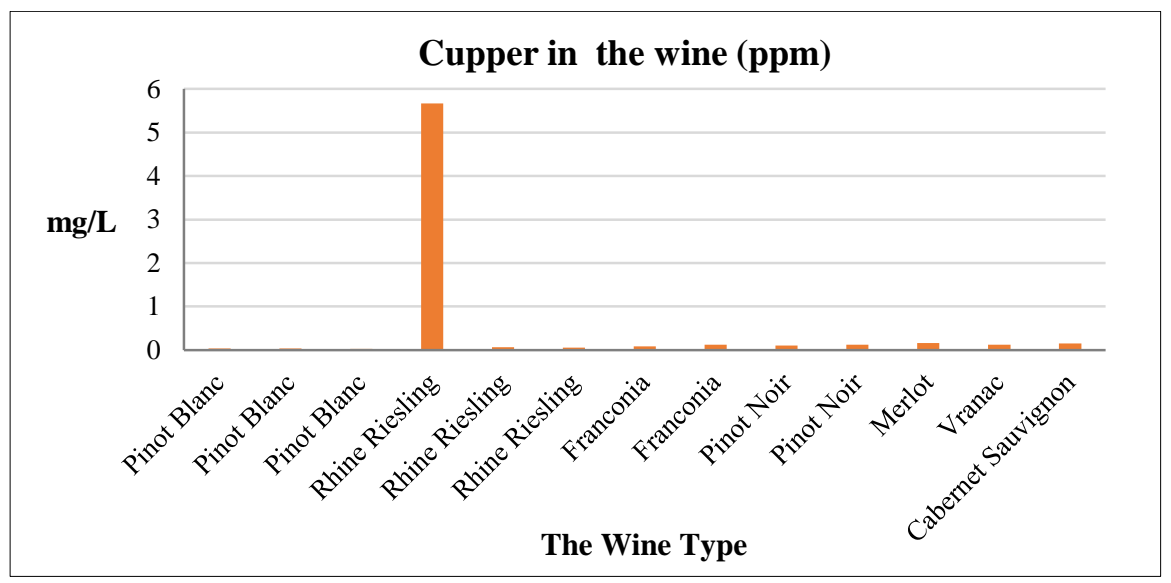

Figure 3. The cupper concentration $(\mathrm{mg} / \mathrm{L})$ in the wine.

Copper is also one of the most frequently occurring heavy metals in wine and can reach the wine via pesticides, brass fittings, and as copper sulphate for treatment of reductive off-flavors. High residual copper can contribute to an enhanced rate of oxidative spoilage, which ultimately results in the browning of the wine, particularly white ones. To minimize the incidence of these problems, it is generally recommended to maintain copper concentration below $0.3-$ $0.5 \mathrm{mg} / \mathrm{L}[10]$.

European Union has sets limit regarding the cupper concentration in the wine, which is less than $0.5 \mathrm{mg} / \mathrm{L}$, while according to the International Organisation of Vine and Wine (OIV) it should be less than $1.0 \mathrm{mg} / \mathrm{l}$. From the obtained results we can see that in contrast to iron, the concentrations of copper in white wines at the bottom of the tanks are larger, although the differences are extremely small, compared to red wines. In red wines as in the case of iron, we can see a higher concentration of copper in the upper part compared to the bottom of the tank. The result that is worth analyzing and discussing is that of the white wine known as Rhine Riesling (Table 3). The obtained result indicates a cupper concentration several times higher $(5 \mathrm{mg} / \mathrm{L})$ than the reference values. At the time of sampling, the sample taken from the bottom of the wine tank is characterized by large impurities. The same sample taken from upper part of the same tank turned out to be at significantly lower values compared to the bottom of the tank. Declines in values for the same sample have also been seen after the clarification process. Sun et al. (2019) [17] indicates that the copper ion concentration falling down was consistent with the trend of yeast growth rising up, meanwhile the copper content was still much less than the initial concentration after fermentation. In terms of wine quality and human health, this is very important because the wine from bottom of the tank during winemaking is dropped out, together with the excessive quantity of heavy metals. Approximately the same values in relation to the cupper concentration in the wine have been reported by other colleagues as well. According to a study in which 72 wines were analyzed, the average copper content was $0.18 \mathrm{mg} / \mathrm{L}$ with a maximum of $0.55 \mathrm{mg} / \mathrm{L}$ [11, 17]. Maciel et al. (2019) [12] indicates that the concentration of copper in all analyzed wine samples has been below (from 1.0 to $10.3 \mu \mathrm{g} \mathrm{L}-1$ ) the maximum acceptable limit set by the OIV $(1000 \mu \mathrm{g} \mathrm{L}-1)$. As a conclusion, all the analyzed samples in relation to the cupper concentration do not pose a risk to the wine stability and human health as well.

Table 4. The concentrations of zinc $(\mathrm{mg} / \mathrm{L})$ in the wine.

\begin{tabular}{cccccc}
\hline Type of Wine & $\begin{array}{c}\text { Year of } \\
\text { Production }\end{array}$ & Country & $\begin{array}{c}\text { The Sampling Part } \\
\text { in the Wine Tank }\end{array}$ & $\begin{array}{c}\text { The Technological Stage } \\
\text { During Winemaking }\end{array}$ & $\begin{array}{c}\text { Zn (mg/L) after } \\
\text { three replication }\end{array}$ \\
\hline Pinot Blanc & 2017 & Kosovo & The bottom & After fermentation & 0.004 \\
Pinot Blanc & 2017 & Kosovo & Upper part & After fermentation \\
Pinot Blanc & 2017 & Kosovo & Upper part & After filtration & 0.000 \\
Rhine Riesling & 2017 & Kosovo & The bottom & After fermentation \\
Rhine Riesling & 2017 & Kosovo & Upper part & After fermentation \\
Rhine Riesling & 2017 & Kosovo & Upper part & After clarification \\
Franconia & 2017 & Kosovo & The bottom & After fermentation \\
Franconia & 2017 & Kosovo & Upper part & After fermentation \\
Pinot Noir & 2017 & Kosovo & The bottom & After fermentation & 0.000 \\
Pinot Noir & 2017 & Kosovo & Upper part & After fermentation & 0.000 \\
Merlot & 2017 & Macedonia & Upper part & After fermentation \\
Vranac & 2017 & Macedonia & Upper part & After fermentation & 0.000 \\
Cabernet Sauvignon & 2017 & Macedonia & Upper part & After fermentation & 0.000 \\
\hline
\end{tabular}




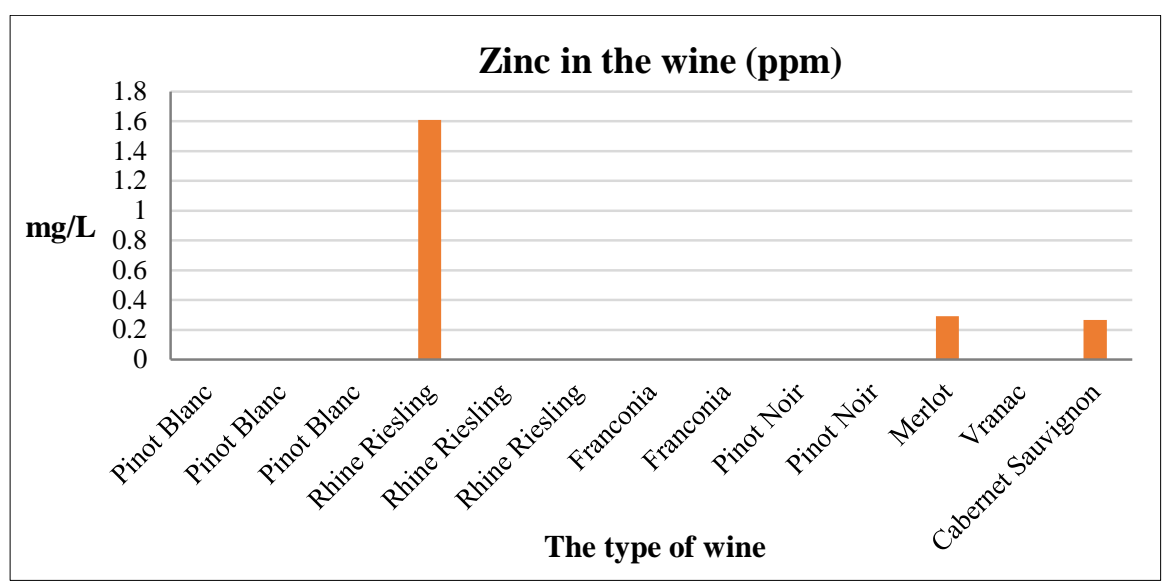

Figure 4. The zinc concentration $(\mathrm{mg} / \mathrm{L})$ in the wine.

Phytosanitary treatments using Bordeaux mixture or zinc $(\mathrm{Zn})$ fungicides are often used in vineyards, which increase soil copper $(\mathrm{Cu})$ and $\mathrm{Zn}$ contents $[13,18]$. The authors found that bentonite fining significantly lowered concentrations of $\mathrm{K}, \mathrm{Cu}, \mathrm{Rb}$, and $\mathrm{Zn}[14,19]$. The values set by the European Union for zinc concentration in the wine are less than $30 \mathrm{mg} / \mathrm{L}$, while according to International Organisation of Vine and Wine (OIV) they should be lower than $5 \mathrm{mg} / \mathrm{L}$. As in the previous two cases, zinc concentrations were within the permissible values. From the obtained results (table 4) we can see that zinc concentrations are at minimum values or virtually nonexistent, excluding any sample where low zinc concentrations has been found. Compared to the wines produced in Kosovo, red wines from Macedonia have been observed to have a slightly higher concentration of zinc, except sample no. 4 (Rhine Riesling). Approximately similar results from the Balkan region have been published by our colleagues as well. In white wine the highest concentration showed $\mathrm{Zn} 0.62 \mathrm{mg} / \mathrm{L}$, and in red-black wine $\mathrm{Cu} 0.238 \mathrm{mg} / \mathrm{L}$ and $\mathrm{Mn} 2.12 \mathrm{mg} / \mathrm{L}$ [15]. The $\mathrm{Cu}$, Fe and $\mathrm{Zn}$ contents in twenty selected wine samples produced in the South-East region of Serbia were determined by flame atomic absorption spectrometry. The $\mathrm{Cu}$ concentrations varied from 0.07 to $0.57 \mathrm{mg} / \mathrm{L}$ in wines, and the $\mathrm{Fe}$ concentrations fluctuated from 2.93 to $36.2 \mathrm{mg} / \mathrm{L}$, while the $\mathrm{Zn}$ levels were in the range from 0.21 to $0.67 \mathrm{mg} / \mathrm{L}$ [7, 20]. The concentrations of zinc found in the analyzed samples do not pose a risk to wine instability, nor do they pose a risk to human health as well.

\section{4- Conclusion}

Based on the results we have obtained, we can conclude that concentrations of the analyzed heavy metals $(\mathrm{Fe}, \mathrm{Cu}$ and $\mathrm{Zn}$ ) in the red wines are greater compared to the white wines, most likely due to the different mode of fermentation. The results show the potential influence of some technological processes during winemaking, such as clarification and filtration, which are carried out with special equipment, and so-called wine pipes which are widely used during winemaking process. Based on our findings and approximately similar results of our colleagues, we recommend that oenology equipments should be cleaned according to the standard cleaning protocols, including the wine pipes, in order to inhibit the induction of increased concentration of heavy metals in the wine. Probably in this process apart from the purity of the equipment, it seems to be very important, also the optimal time of sediment formation in both types of wines. Regarding to this, any movement of the wine can potentially disturb the wine sediment and thus can increase the concentration of heavy metals in the upper part of the wine tank. Special attention should also be paid to the process of grape and vineyard spraying with different chemical substances, then the proper use and according to the standards of clarifying agents, the proper use of different additives during winemaking, etc. All of these can lead to a potential increase in the concentration of heavy metals in the final product. We recommend colleagues to do as much as possible analysis and research of heavy metals in the wine, especially in relation to the metal oenological equipment used by different wineries. From the obtained results, as well as with a serious commitment during wine packaging and the storage, these wines will likely retain their optimal organoleptic properties. Finally we can conclude that all analyzed wine samples will not pose any risk in the future to human health

\section{5- Acknowledgments}

This paper and the research behind it would not have been possible without the exceptional support of my colleagues from Department of Food Sciences and Biotechnology; Suzana Aliu, Fisnik Laha and Fidan Feka.

\section{6- Conflict of Interest}

The author declares that there is no conflict of interests regarding the publication of this manuscript. In addition, the ethical issues, including plagiarism, informed consent, misconduct, data fabrication and/or falsification, double publication and/or submission, and redundancies have been completely observed by the authors. 


\section{7- References}

[1] Gadzhieva, A. "Iron, copper and zinc determination in wine using flame atomic absorption spectroscopy." Applications Chemist, Thermo Fisher Scientific, Cambridge, UK (2016).

[2] Tariba, Blanka. "Metals in Wine-Impact on Wine Quality and Health Outcomes." Biological Trace Element Research 144, no. 1-3 (April 9, 2011): 143-156. doi:10.1007/s12011-011-9052-7.

[3] Bentlin, Fabrina R. S, Fernando H Pulgati, Valderi L Dressler, and Dirce Pozebon. "Elemental Analysis of Wines from South America and Their Classification According to Country." Journal of the Brazilian Chemical Society 22, no. 2 (February 2011): 327-336. doi:10.1590/s0103-50532011000200019.

[4] Minilu Woldemariam, Daniel, and Bhagwan Singh Chandravanshi. "Concentration Levels of Essential and Non-Essential Elements in Selected Ethiopian Wines.” Bulletin of the Chemical Society of Ethiopia 25, no. 2 (May 3, 2011). doi: $10.4314 /$ bcse.v25i2.65852.

[5] Płotka-Wasylka, Justyna, Małgorzata Rutkowska, Bartłomiej Cieślik, Alan Tyburcy, and Jacek Namieśnik. "Determination of Selected Metals in Fruit Wines by Spectroscopic Techniques." Journal of Analytical Methods in Chemistry 2017 (2017): 1-9. doi:10.1155/2017/5283917.

[6] Banović, M., J. Kirin, N. Ćurko, and K. Kovačević Ganić. "Influence of Vintage on $\mathrm{Cu}, \mathrm{Fe}, \mathrm{Zn}$ and Pb Content in Some Croatian Red Wines." Czech Journal of Food Sciences 27, no. Special Issue 1 (June 24, 2009): S401-S403. doi:10.17221/597cjfs.

[7] Kostic, Danijela, Snezana Mitic, Gordana Miletic, Sasa Despotovic, and Aleksandra Zarubica. "The Concentrations of Fe, Cu and $\mathrm{Zn}$ in Selected Wines from South-East Serbia.” Journal of the Serbian Chemical Society 75, no. 12 (2010): 1701-1709. doi:10.2298/jsc100104133k.

[8] Angelova, Violina, Angel Ivanov, Dimitar Braikov, and Krasimir Ivanov. "Heavy Metal ( $\mathrm{Pb}, \mathrm{Cu}, \mathrm{Zn}$ and $\mathrm{Cd}) \mathrm{Content}$ in Wine Produced from Grape Cultivar Mavrud, Grown in an Industrially Polluted Region.” OENO One 33, no. 3 (September 30, 1999): 119. doi:10.20870/oeno-one.1999.33.3.1022.

[9] Dumitriu (Gabur), G.-D., C. Teodosiu, I. Morosanu, O. Jitar, and V.V. Cotea. "Quantification of Toxic Metals During Different Winemaking Stages.” Edited by P. Roca. BIO Web of Conferences 15 (2019): 02024. doi:10.1051/bioconf/20191502024.

[10] Pyrzynska, Krystyna. "Chemical Speciation and Fractionation of Metals in Wine." Chemical Speciation \& Bioavailability 19, no. 1 (January 2007): 1-8. doi:10.3184/095422907x198040.

[11] Claus, Harald. "How to Deal with Uninvited Guests in Wine: Copper and Copper-Containing Oxidases.” Fermentation 6, no. 1 (March 24, 2020): 38. doi:10.3390/fermentation6010038.

[12] Maciel, Juliana, Michele Souza, Lisiane Silva, and Daiane Dias. "Direct Determination of $\mathrm{Zn}, \mathrm{Cd}, \mathrm{Pb}$ and $\mathrm{Cu}$ in Wine by Differential Pulse Anodic Stripping Voltammetry.” Beverages 5, no. 1 (January 11, 2019): 6. doi:10.3390/beverages5010006.

[13] Korchagin, Jackson, Diovane Freire Moterle, Pedro Alexandre Varella Escosteguy, and Edson Campanhola Bortoluzzi. "Distribution of Copper and Zinc Fractions in a Regosol Profile Under Centenary Vineyard." Environmental Earth Sciences 79, no. 19 (September 23, 2020). doi:10.1007/s12665-020-09209-7.

[14] Ronkainen, Niina J. "Determination of Trace Elements in Wine by Atomic Spectroscopy and Electroanalytical Methods." Grape and Wine Biotechnology (October 19, 2016). doi:10.5772/64932.

[15] Halili, Jeton, Altin Mele, Tahir Arbneshi, and Adelina Halili. "Determination of Some Heavy Metals in the Soil, Grape and Wine of the Grape Vineyards of Rahovec." Journal of International Environmental Application and Science 10, no. 1 (2015): 96-101.

[16] SUN, Xiangyu, Lingling LIU, Tingting MA, Jing YU, Weidong HUANG, Yulin FANG, and Jicheng ZHAN. "Effect of High $\mathrm{Cu} 2+$ Stress on Fermentation Performance and Copper Biosorption of Saccharomyces Cerevisiae During Wine Fermentation." Food Science and Technology 39, no. 1 (March 2019): 19-26. doi:10.1590/1678-457x.24217.

[17] Blesic, M., Maja Drmac, Kristina Batinic, Nermina Spaho, Mirela Smajic Murtic, M. Zele, et al. "Levels of Selected Metals in Wines from Different Herzegovinian Viticultural Localities.” Croatian Journal of Food Science and Technology 9, no. 1 (June 7, 2017): 1-10. doi:10.17508/cjfst.2017.9.1.01.

[18] Dokić, Dragan, Mirna Gavran, Maja Gregić, and Vesna Gantner. "The Impact of Trade Balance of Agri-Food Products on the State's Ability to Withstand the Crisis." HighTech and Innovation Journal 1, no. 3 (September 1, 2020): $107-111$. doi:10.28991/hij-2020-01-03-02.

[19] Mira, Helena, P. Leite, Sofía Catarino, J. M. Ricardo-da-Silva, and A. S. Curvelo-Garcia. "Metal reduction in wine using PVIPVP copolymer and its effects on chemical and sensory characters." VITIS-Journal of Grapevine Research 46, no. 3 (2015): 138. doi:10.5073/vitis.2007.46.138-147.

[20] Pohl, Pawel. "What Do Metals Tell Us About Wine?” TrAC Trends in Analytical Chemistry 26, no. 9 (October 2007): 941949. doi:10.1016/j.trac.2007.07.005. 